\title{
The microbial ferrous wheel: iron cycling in terrestrial, freshwater, and marine environments
}

\author{
David Emerson ${ }^{1 *}$, Eric Roden ${ }^{2}$ and Benjamin S. Twining ${ }^{1}$ \\ ${ }^{1}$ Bigelow Laboratory for Ocean Sciences, East Boothbay, ME, USA \\ 2 Department of Geoscience, University of Wisconsin, Madison, WI, USA \\ *Correspondence: demerson@bigelow.org \\ Edited by: \\ Bradley M. Tebo, Oregon Health and Science University, USA \\ Reviewed by: \\ Bradley M. Tebo, Oregon Health and Science University, USA
}

Were Oscar Wilde a devotee of iron biogeochemistry in the twenty-first century (hard as that might be to imagine), he might remark that iron is the most ironic of elements. Those interested in microbes that carry out life-sustaining iron-coupled redox reactions like to point out that iron is, after oxygen, the most abundant redox-active element in the Earth's crust. However, those studying oceanic phytoplankton regard iron as a nutrient that occurs at such vanishingly low concentrations in the surface ocean that it limits the growth of algae in more than $40 \%$ of the global ocean. This is because at the $\mathrm{pH}$ of seawater oxygen promotes the rapid oxidation of soluble ferrous iron to insoluble ferric iron oxyhydroxides that precipitate and sink out of the water column. As a result, while many marine microbes, and especially the photosynthetic ones, have developed finely-tuned mechanisms for acquiring iron, total primary productivity can be limited by iron.

At oceanic hydrothermal vents, and in terrestrial habitats, iron is not a limiting nutrient. At many oxic-anoxic interfacial habitats, not only is iron not limiting, but it is so abundant that lithotrophic microbes can use it as an electron source to sustain growth, and form robust communities of iron-oxidizing chemolithoautotrophs. In more acidic conditions, such as certain hot springs and acid mine drainage systems, ferrous iron is more stable, concentrations can be in the millmolar range, and specific communities of archaea and bacteria that use iron as an energy source can flourish. Iron-oxidizing microbes are not limited to aerobic habitats, but can also oxidize iron under anaerobic conditions by coupling the oxidation to either anoxygenic photosynthesis or nitrate reduction. Nor does it appear that they are limited to only utilizing soluble ferrous iron as an energy source, but can also acquire iron from insoluble minerals that contain reduced iron.

But iron-oxidation is only one-half of the equation. The utilization of ferric iron, principally in the form of Fe-oxides, to carry out anaerobic respiration is well established as an important pathway for organic carbon metabolism in anaerobic habitats. Furthermore, model organisms such as Shewanella and Geobacter are utilized to study the biochemical mechanisms of Fe-reduction, and from this we have learned a good deal about processes involved in extracellular electron transfer. Taken as a whole, it is apparent that the iron cycle is a remarkably complex process, dependent upon a wide range of chemical interactions, habitat types and groups of microbes that link it to all of Earth's other important biogeochemical cycles.

In this special topic issue we have gathered contributions from scientists working in diverse disciplines who have common interests in iron cycling at the process level and at the organismal level, from the perspective of iron as an energy source or as a limiting nutrient for primary productivity in the ocean. The hope is that bringing together seemingly disparate lines of research under one cover will result in a more global understanding of the iron cycle, and perhaps draw new insight into the connections within the cycle. We were very fortunate to enlist a varied and talented group of authors to contribute a wide range of articles. In total, 16 papers have been included, with a mixture of 9 original research articles, 6 reviews, and 1 perspective.

Aspects of iron cycling in the open ocean are covered by reviews on organic complexation (Gledhill and Buck, 2012) and on the role of superoxide dismutase (Rose, 2012), as well as in a research article on the role of weak iron-binding ligands in the ocean by Croot and Heller (2012). Oxygen-dependent iron oxidation at circumneutral $\mathrm{pH}$ is addressed in a research paper on a potential mechanism for iron oxidation by Liu et al. (2012), a research paper on mineralogy of biogenicallyformed oxides at a hydrothermal vent (Toner et al., 2012), and a review of iron-based ecosystems associated with hydrothermal vents and the subsurface in the Pacific by Kato et al. (2012). Iron-cycling in acidic systems is reviewed by Johnson et al. (2012), and original research on a unique iron-rich acidic ecosystem in Yellowstone National Park is presented by Kozubal et al. (2012). A novel spectroscopic technique for biochemical analysis of iron oxidation in Leptospirillum ferroxidans is contributed by Blake and Griff (2012). Microbial utilization of iron under anaerobic conditions is dealt with in a review of mechanisms for iron reduction by Shi et al. (2012). Picardal (2012) reviews abiotic and microbial interactions of anaerobic iron oxidation and Carlson et al. (2012) provide an interesting perspective piece on nitrate-dependent iron oxidation. Original research on iron reduction in Shewanella is presented by Coursolle and Gralnick (2012), and competition among phototrophic and nitrate-dependent iron-oxidizing microbes is 
addressed by Melton et al. (2012). Finally, original work from the laboratory of Eric Roden investigates redox cycling in a typical freshwater iron-rich stream (Roden et al., 2012), as well as the capacity for microbes to use iron minerals as an iron source (Shelobolina et al., 2012).

\section{REFERENCES}

Blake, I. I. R. C., and Griff, M. N. (2012). In situ spectroscopy on intact Leptospirillum ferrooxidans reveals that reduced cytochrome 579 is an obligatory intermediate in the aerobic iron respiratory chain. Front. Microbio. 3:136. doi: 10.3389/fmicb.2012.00136

Carlson, H. K., Clark, I. C., Melnyk, R. A., and Coates, J. D. (2012). Toward a mechanistic understanding of anaerobic nitrate-dependent iron oxidation: balancing electron uptake and detoxification. Front. Microbio. 3:57. doi: 10.3389/fmicb.2012.00057

Coursolle, D., and Gralnick, J. A. (2012). Reconstruction of extracellular respiratory pathways for iron(III). Reduction in Shewanella oneidensis strain MR-1. Front. Microbio. 3:56. doi: 10.3389/fmicb.2012.00056

Croot, P. L., and Heller, M. I. (2012). The importance of kinetics and redox in the biogeochemical cycling of iron in the surface ocean. Front. Microbio. 3:219. doi: 10.3389/fmicb.2012.00219

Gledhill, M., and Buck, K. N. (2012). The organic complexation of iron in the marine environment: a review. Front. Microbio. 3:69. doi: 10.3389/fmicb.2012.00069
Johnson, D. B., Kanao, T., and Hedrich, S. (2012). Redox transformations of iron at extremely low $\mathrm{pH}$ : fundamental and applied aspects. Front. Microbio. 3:96. doi: 10.3389/fmicb.2012.00096

Kato, S., Nakamura, K., Toki, T., Ishibashi, J.-I., Tsunogai, U., Hirota, A., et al. (2012). Iron-based microbial ecosystem on and below the seafloor: a case study of hydrothermal fields of the southern mariana trough. Front. Microbio. 3:89. doi: 10.3389/fmicb.2012.00089

Kozubal, M. A., Macur, R. E., Jay, Z. J., Beam, J. P., Malfatti, S. A., Tringe, S. G., et al. (2012). Microbial iron cycling in acidic geothermal springs of Yellowstone National Park: integrating molecular surveys, geochemical processes, and isolation of novel Fe-active microorganisms. Front. Microbio. 3:109. doi: 10.3389/fmicb.2012.00109

Liu, J., Wang, Z., Belchik, S. M., Edwards, M. J., Liu, C., Kennedy, D. W., et al. (2012). Identification and characterization of MtoA: a decaheme c-type cytochrome of the neutrophilic $\mathrm{Fe}(\mathrm{II})$-oxidizing bacterium Sideroxydans lithotrophicus ES-1. Front. Microbio. 3:37. doi:

Melton, E. D., Schmidt, C., and Kappler, A. (2012). Microbial 10.3389/fmicb.2012.00037

Taken together these papers present an overview of research on iron from a range of perspectives that indicates the breadth of work that has been done and provides insight into the many exciting avenues of research that continue to enhance our understanding of the iron cycle in nature.

iron(II). Oxidation in littoral freshwater lake sediment: the potential for competition between phototrophic vs. nitratereducing iron(II)-oxidizers. Front. Microbio. 3:197. doi: 10.3389/fmicb.2012.00197

Picardal, F. (2012). Abiotic and microbial interactions during anaerobic transformations of $\mathrm{Fe}(\mathrm{II})$ and $\mathrm{NO}_{\mathrm{x}}^{-}$. Front. Microbio. 3:112. doi: 10.3389/fmicb.2012.00112

Roden, E. E., McBeth, J. M., Blöthe, M., Percak-Dennett, E. M., Fleming, E. J., Holyoke, R. R., et al. (2012). The microbial ferrous wheel in a neutral $\mathrm{pH}$ groundwater seep. Front. Microbio. 3:172. doi 10.3389/fmicb.2012.00172

Rose, A. L. (2012). The influence of extracellular superoxide on iron redox chemistry and bioavailability to aquatic microorganisms. Front. Microbio. 3:124. doi: 10.3389/fmicb.2012.00124

Shelobolina, E., Konishi, H., Xu, H., Benzine, J., Xiong, M. Y., $\mathrm{Wu}$, T., et al. (2012). Isolation of phyllosilicate-iron redox cycling microorganisms from an illitesmectite rich hydromorphic soil. Front. Microbio. 3:134. doi: 10.3389/fmicb.2012.00134

Shi, L., Rosso, K. M., Clarke, T. A., Richardson, D. J., Zachara, J. M., and Fredrickson, J. K. (2012). Molecular underpinnings of $\mathrm{Fe}(\mathrm{III})$ oxide reduction by Shewanella oneidensis MR-1. Front. Microbio. 3:50. doi: 10.3389/fmicb.2012. 00050

Toner, B. M., Berquó, T. S., Michel, F. M., Sorensen, J. V., Templeton, A. S., and Edwards, K. J. (2012). Mineralogy of iron microbial mats from loihi seamount. Front. Microbio. 3:118. doi 10.3389/fmicb.2012.00118

Received: 02 October 2012; accepted: 14 October 2012; published online: 31 October 2012.

Citation: Emerson D, Roden $E$ and Twining BS (2012) The microbial ferrous wheel: iron cycling in terrestrial, freshwater, and marine environments. Front. Microbio. 3:383. doi: 10.3389/ fmicb.2012.00383

This article was submitted to Frontiers in Microbiological Chemistry, a specialty of Frontiers in Microbiology.

Copyright () 2012 Emerson, Roden and Twining. This is an open-access article distributed under the terms of the Creative Commons Attribution License, which permits use, distribution and reproduction in other forums, provided the original authors and source are credited and subject to any copyright notices concerning any third-party graphics etc. 